\title{
VOLTAMMETRIC AND RP-LC ASSAY FOR THE ANTIDEPRESSANT DRUG MIRTAZAPINE: A VALIDATED METHOD FOR THE PHARMACEUTICAL DOSAGE FORM
}

\author{
Fatma Ağınn', Nurgül Karadaş,3, Bengi Uslü ${ }^{2 *}$, Sibel A. Özkan² \\ ${ }^{1}$ Karadeniz Technique University, Faculty of Pharmacy, Dept. of Analytical Chemistry, \\ Trabzon, Turkey \\ ${ }^{2}$ Ankara University, Faculty of Pharmacy, Dept. of Analytical Chemistry, \\ 06100, Ankara, Turkey \\ ${ }^{3}$ Hitit University, Faculty of Science and Arts, Dept. of Chemistry, Corum, Turkey \\ buslu@pharmacy.ankara.edu.tr
}

In the present paper, rapid, sensitive, selective, accurate and precise analytical methodologies were developed for the determination of the antidepressant drug mirtazapine (MIR) using voltammetry and liquid chromatography. In cyclic voltammetry (CV), MIR showed one sharp oxidation peak and one additional wave in acidic media in the anodic direction; at $\mathrm{pH} 5.50$, the mirtazapine peak was single and sharp. Under optimized conditions, the peak current showed a linear dependence with concentration in the range between 0.212 and $26.54 \mu \mathrm{g} / \mathrm{ml}$ for glassy carbon (GC) and 1.06 and $26.54 \mu \mathrm{g} / \mathrm{ml}$ for borondoped diamond (BDD) electrodes using differential pulse (DP) and square wave (SW) voltammetric techniques. The possible oxidation mechanisms are also discussed. A simple and fully validated reverse phase-liquid chromatography (RP-LC) method to test for MIR in tablets was developed using an X-Select RP-18 column $(250 \times 4.60 \mathrm{~mm}$ ID $\times 5 \mu \mathrm{m})$ at $25^{\circ} \mathrm{C}$ with methanol : water $(30: 70, V / V$, containing $15 \mathrm{mM} o$-phosphoric acid) as the mobile phase adjusted to pH 3.0. The RP-LC method allowed quantification over a MIR concentration range of 1.0-18.0 $\mu \mathrm{g} / \mathrm{ml}$. MIR was exposed to thermal, photolytic, or oxidative stress, as well as acid and base hydrolysis conditions, and the stressed samples were assayed by the proposed LC method. The proposed methods allow for a number of cost- and time-saving benefits.

Keywords: mirtazapine; voltammetry; liquid chromatography; stability-indicating studies; drug analysis

\section{ВОЛТАМЕТРИСКО И RP-LС ОПРЕДЕЛУВАЊЕ НА АНТИДЕПРЕСИВНИОТ ЛЕК МИРТАЗАПИН: ВАЛИДИРАНА МЕТОДА ЗА ОПРЕДЕЛУВАњЕ ФАРМАЦЕВТСКА ДОЗИРНА ФОРМА}

Во овој труд е опишан развојот на брза, осетлива, селективна точна и прецизна аналитичка методологија за определување на антидепресивот Mirtazapine (MIR) со помош на волтаметрија и течна хроматографија. Во цикличната волтаметрија (CV), MIR дава еден остар оксидациски пик и еден додатен сигнал во кисела средина во анодната област, додека во областа над рН 5,50 mirtazapine дава единичен и остар сигнал. При оптимизирани услови, пикот на струјата покажува линеарна зависност од концентрацијата во областа меѓу 0,212 и 26,54 $\mu \mathrm{g} / \mathrm{ml}$ co GC-електродата (од анг. glassy carbon) и меѓу1,06 и 26, 54 $\mu \mathrm{g} / \mathrm{ml}$ co BDD-електродата (од анг. boron-doped diamond) со помош на диференцијалната пулсна (DP) и квадратно-бранова (SW) волтаметриска техника. Исто така се дискутирани веројатните механизми на оксидација. Развиена е едноставна, целосно валидирана RP-LC метода за определување на MIR во таблети со колона од типот X-Select RP-18 $(250 \times 4,60 \mathrm{~mm}$ ID $\times 5 \mu \mathrm{m})$ на $25^{\circ} \mathrm{C}$ со мобилна фаза во смеса метанол: вода $(30: 70, V / V) 15 \mathrm{mM}$ o-фосфорна киселина и $\mathrm{pH} 3,0$. Со оваа метода е овозможено квантитативно определување на MIR во областа од 1,0 до $18,0 \mu \mathrm{g} / \mathrm{ml}$. Предложената LC метода овозможува испитување на примероци од MIR после термичко, фотолитичко и оксидационо третирање, како и при кисела и базна хидролиза. Предложените методи овозможуваат заштеди во цената и времето за анализа.

Клучни зборови: миртазапин; волтаметрија; течна хроматографија; испитување на стабилност; анализа на лек 


\section{INTRODUCTION}

Mirtazapine (MIR; Scheme 1), (1,2,3,4, 10,14b-hexahydro-2-methylpyrazino[2,1-a] pyrido[2,3-c] benzazepine, is a tetracyclic piperazinoazepine, and has a different structure from any other currently used antidepressant. It enhances central noradrenergic and serotonergic activity by blocking $\alpha_{2}$ receptors and selectively antagonizing 5HT2 and 5HT3 receptors. MIR is well absorbed without regard to food intake. It demonstrates linear kinetics over its usual dosage range and reaches a peak plasma level approximately two hours after an oral dose. It is metabolized in the liver via the P450 cytochrome oxidase pathway. Plasma protein binding is about $85 \%$. The $\mathrm{N}$-desmethyl metabolite is pharmacologically active. Elimination occurs via urine $(75 \%)$ and feces $(15 \%)$. Clearance of the drug is diminished in the presence of liver or renal impairment. Therefore, a lower dosage is recommended in the elderly and patients with liver or renal disfunction [1-4].

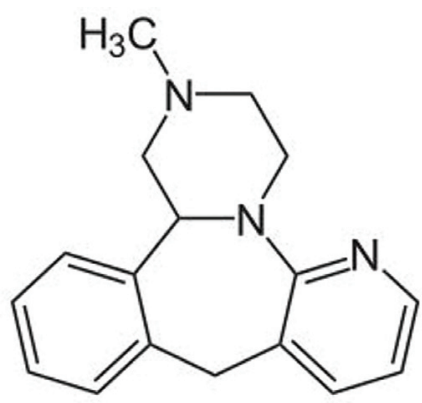

Scheme 1. Structure of MIR

Various analytical methods have been used to determine MIR in various samples, such as liquid chromatography [5-10], spectrofluorimetry [10-12] and spectrophotometry $[10,13$, 14]. A survey of the literature reveals that no electrochemical data are available concerning the voltammetric behavior of MIR. Additionally, to our knowledge, there is no information about its electrochemical redox properties at present. Moreover, no monograph of MIR has been reported in the official pharmacopeias as of today.
Electroanalytical methods have proved to be highly sensitive for the analysis of drugs in pharmaceutical dosage forms and biological samples owing to their straightforwardness, low cost, and relatively short analysis time compared to the other analytical techniques [15-20]. Voltammetric techniques are most suitable for investigating the redox properties of active drug compounds. This can give insight into the metabolic fate, in vivo redox process or pharmaceutical activity [21-26].

Owing to the widespread use of the LCUV method in routine analysis, it is important that specific and validated LC methods are used for the analysis of an active drug compound in its pharmaceutical dosage form. LC-UV methods offer important advantages, such as low cost, and have proven to be a valuable method in the quality control of active drug substances.

The first purpose of the present study was to carry out a detailed investigation about the voltammetric behavior and analysis of MIR at carbon-based electrodes using cyclic, linear sweep (LS) and pulse voltammetric techniques. Secondly, the determination of MIR using RP-LC techniques with a stability test was performed on as per ICH norms.

\section{EXPERIMENTAL}

Mirtazapine and its pharmaceutical dosage form Zestat ${ }^{\circledR}$ tablets were kindly supplied by Abdi Ibrahim Pharm. Ind. (Istanbul, Turkey). The model compound and internal standard (IS), as well as pimozide, quetiapine fumarate, pioglitazone hydrochloride, rosiglitazone maleate and amlodipine besylate were kindly supplied by different companies in Turkey. All chemicals for the preparation of buffers and supporting electrolytes were reagent grade (Merck or Sigma).

For the voltammetric method, stock solutions of MIR $(265.4 \mu \mathrm{g} / \mathrm{ml})$ were prepared in methanol and kept in the dark in a refrigerator at about $4^{\circ} \mathrm{C}$. MIR working solutions for the voltammetric investigations were prepared by 
dilution of the stock solution and contained 10\% methanol for $\mathrm{pH}$ studies. Sulfuric acid solutions $(0.1$ and $0.5 \mathrm{M})$, phosphate buffer $(0.2 \mathrm{M}, \mathrm{pH}$ 2.0-8.0), acetate buffer $(0.2 \mathrm{M}, \mathrm{pH} 3.5-5.5)$ and Britton-Robinson buffer (0.04 M, pH 2.0-12.0) were used as the supporting electrolytes. The calibration graphs were constructed by plotting the peak current against the corresponding MIR concentration in the range between 0.212 and $26.54 \mu \mathrm{g} / \mathrm{ml}$ for both methods using GC and 0.212 and $26.54 \mu \mathrm{g} / \mathrm{ml}$ for DP and 1.06 and $26.54 \mu \mathrm{g} / \mathrm{ml}$ for $\mathrm{SW}$ voltammetric techniques using BDD electrodes.

All chemicals were analytical reagent grade and all solvents were HPLC grade. For the LC method, HPLC grade methanol (Merck, Darmstadt, Germany) was used as an organic modifier. Sodium hydroxide (Merck, Darmstadt, Germany) and $o$-phosphoric acid (Riedel-de Haen, Germany) were used for $\mathrm{pH}$ adjustment. Water with conductivity lower than $0.05 \mu \mathrm{S} / \mathrm{cm}$ for RP-LC studies was obtained with a Zeneer Power I apparatus (Human Corp.). Standard stock solutions of MIR and the IS hydrochlorothiazide were prepared in methanol and water, respectively, at a concentration of approximately $100 \mu \mathrm{g} / \mathrm{ml}$; working solutions were prepared by dilution using the mobile phase. The concentration of MIR for LC studies was varied in the range of $1.0-18 \mu \mathrm{g} / \mathrm{ml}$. The concentration of IS was maintained at a constant level of $5.0 \mu \mathrm{g} / \mathrm{ml}$. The RP-LC method provides a straightforward and sensitive procedure for the determination of MIR at low concentrations in pharmaceutical dosage forms by UV detection at $230 \mathrm{~nm}$. With the LC method, different mobile phase compositions and ratios were employed to obtain efficient and reproducible results. The best resolution and peak shape was obtained with the X-Select-C18 $(250 \times 4.60 \mathrm{~mm}$, ID $5 \mu \mathrm{m}$ ) column at $25^{\circ} \mathrm{C}$. The influence of $\mathrm{pH}$ on the mobile phase was examined in order to optimize the chromatographic conditions for LC determination of MIR and the IS. $230 \mathrm{~nm}$ was selected for detection because it showed greater sensitivity and linearity than the others.
The calibration curves for LC analysis were constructed by plotting the ratio of the peak area of the drug to that of the IS against the drug concentration. Ruggedness and precision were checked on different days as within day $(n=5)$ and between days $(n=5)$ variability. Relative standard deviations (RSD) were calculated to check the ruggedness and precision of the method [27-29]. The accuracy and precision of the developed methods are described in a quantitative fashion by the use of Bias \% (relative error). All stock and working solutions were protected from light and stored in fridge at about $4{ }^{\circ} \mathrm{C}$.

\subsection{Equipment and conditions}

Voltammetric measurements were recorded using BAS 100W (Bioanalytical Systems, USA) Electrochemical Analyzer with a standard three-electrode configuration. The three electrode system consisted of either a BDD (Windsor Scientific Ltd., diameter $3 \mathrm{~mm}$ ) or a $\mathrm{GC}$ (BAS, diameter $3 \mathrm{~mm}$ ) working electrode, with a platinum wire auxiliary electrode and an $\mathrm{Ag} / \mathrm{AgCl}$ reference electrode $(\mathrm{KCl} 3 \mathrm{M}$, BAS) and a standard one-compartment threeelectrode cell with $10 \mathrm{ml}$ capacity. Controlled potential coulometric experiments were carried out in an electrochemical cell using Autolab Potentiostat/Galvanostat PGSTAT 302 with GPES 4.9.

BDD and GC electrodes were polished manually with an aqueous slurry of alumina powder (diameter $0.01 \mu \mathrm{m}$ ) on a damp smooth polishing cloth (BAS velvet polishing pad) immediately before each measurement. All measurements were performed at room temperature. For voltammetric studies, the $\mathrm{pH}$ measurements were performed using a $\mathrm{pH}$ meter. A Model 538 (WTW, Austria) combined glass and reference electrode with an accuracy of $0.05 \mathrm{pH}$ units was used.

Operating conditions for DPV were: pulse amplitude, $50 \mathrm{mV}$; pulse width, $50 \mathrm{~ms}$; scan rate, $20 \mathrm{mV} \cdot \mathrm{s}^{-1}$; for $\mathrm{SWV}$ were: pulse 
amplitude, $25 \mathrm{mV}$; frequency, $15 \mathrm{~Hz}$; potential step, $4 \mathrm{mV}$.

The RP-LC analysis was carried out on a Shimadzu HPLC system with a pump (LC-20 AD), a DAD detection system (SPD-M 20A) and column oven (CT020 AC). This equipment has a degasser system (DGU $20 \mathrm{~A}$ ). The system operated at $230 \mathrm{~nm}$. An X-Select Reverse Phase-18 $(250 \times 4.6 \mathrm{~mm}$ ID $\times 5 \mu \mathrm{m}$, Waters $)$ column was used as the stationary phase at $25^{\circ} \mathrm{C}$ and hydrochlorothiazide (IS) was chosen as the internal standard because of its shorter retention time and better peak shapes than the other potential internal standards.

\subsection{Generation of stressed samples for the establishment of a stability-indicating assay}

Degradation studies were attempted to stress conditions of exposure to UV light, acid, base, oxidation and heat in an oven (at $75^{\circ} \mathrm{C}$ ) to evaluate the ability of the proposed chromatographic method to separate MIR from its degradation product [28]. Thermal and photodegradation of MIR in the raw material were carried out in the solid state. After degradation, stock solutions were prepared by dissolution in methanol to achieve a final concentration of 1 $\mathrm{mg} / \mathrm{ml}$.

From these solutions, aliquot were diluted with the mobile phase to achieve a final concentration of $100 \mu \mathrm{g} / \mathrm{ml}$. A peak purity test was performed for the MIR peak using DAD in the stressed samples. The optimized method was used to study the forced degradation behavior of MIR and may also be applied in stability testing of pharmaceutical dosage forms. An appropriate blank was injected before analysis of the stressed samples. For thermal stress testing, a sample of the drug substance was placed in a controlled-temperature oven at 75 ${ }^{\circ} \mathrm{C}$ for $24 \mathrm{~h}$.

Acidic, alkaline, and oxidative degradation solutions were prepared by dissolving the raw material (MIR) in methanol. From this so- lution, aliquots were diluted with $\mathrm{HCl}, \mathrm{NaOH}$ and $\mathrm{H}_{2} \mathrm{O}_{2}$ to achieve a concentration of $100 \mu \mathrm{g} /$ $\mathrm{ml}$ for each solution. Acid and alkaline hydrolyses of MIR in the solution state were conducted with $0.5 \mathrm{M}$ and $1.0 \mathrm{M} \mathrm{HCl}$ and $0.5 \mathrm{M}$ and $1.0 \mathrm{M} \mathrm{NaOH}$ at $80{ }^{\circ} \mathrm{C}$ for $30 \mathrm{~min}$. For oxidative stress, sample solutions of MIR in the solution state with $3 \%$ and $30 \% \mathrm{H}_{2} \mathrm{O}_{2}$ were kept at $80{ }^{\circ} \mathrm{C}$ for $30 \mathrm{~min}$. For photolytic stress, samples of the drug substance in the solid state were irradiated with UV radiation at $254 \mathrm{~nm}$ for $24 \mathrm{~h}$.

\subsection{Tablet assay procedure and recovery}

For both the voltammetric and RP-LC methods, ten Zestat ${ }^{\circledR}$ (Abdilbrahim Pharm. Int, Istanbul) tablets, each containing $30 \mathrm{mg}$ of MIR, were accurately weighed and crushed to a homogeneous fine powder in a mortar. An accurate weight of this powder, equivalent to one tablet content, was weighed, transferred into a $100 \mathrm{ml}$ calibrated flask, diluted with methanol stirred for about $10 \mathrm{~min}$ and then completed to the volume with the same solution. The solution was filtered and the clear filtrate was collected in a clean flask. Appropriate solutions were prepared by taking suitable aliquots of the clear filtrate (for the LC study, by adding a constant amount of IS) and diluting them with the selected supporting electrolyte (final solution contained $10 \%$ and $30 \%$ methanol for voltammetry and LC, respectively) and with mobile phase for the voltammetric and RP-LC methods, respectively, in order to obtain a final solution. The amount of MIR was calculated from the corresponding regression equations.

In order to demonstrate the applicability of the proposed methods, recovery experiments were performed by adding a known amount of pure MIR to pre-analyzed tablets. Known amounts of pure MIR (and at a constant level of the IS for the LC method) were added to the tablet dosage form and the mixtures were analyzed. The percent recovery was calculated by comparing the concentration obtained from spiked samples with the actual added concentration. Thus, the effect of common excipients in tablet dosage 
forms on voltammograms (e.g. shifting of the peak potential or changing the peak shape) or on chromatograms (e.g., tailing, broadening) was investigated. Recovery experiments from tablets also showed the reliability, accuracy and suitability of the methods.

\section{RESULTS AND DISCUSSION}

\subsection{Voltammetric behavior of MIR}

No previous detailed electrochemical studies are available, either concerning the electrode behavior or the sensitive electroanalytical determination of MIR. To demonstrate the usefulness of carbon-based electrodes for the determination of MIR, which may offer advantages for the use of such electrodes as sensors, the voltammetric behavior of MIR on GC and BDD electrodes was investigated in detail in this study. In order to understand the electrochemical process occurring at carbon-based electrodes, cyclic, linear sweep (LS) DP and SW voltammetry were carried out. MIR showed one sharp irreversible oxidation peak and one additional wave in acidic media at $1.15 \mathrm{~V}$ and $1.3 \mathrm{~V}$, respectively; above $\mathrm{pH} 5.50$, its electrochemical response became one sharp peak at about $0.90 \mathrm{~V}$ on GCE (Figure 1). However, MIR was oxidized on the BDD electrode and gave a well-defined peak and ill-defined anodic wave between $\mathrm{pH}$ 1.0-5.0 in all types of supporting electrolyte. Above $\mathrm{pH} 5.0$ the anodic oxidation of MIR occurred with only one well-defined peak at about $1.0 \mathrm{~V}$, depending on the $\mathrm{pH}$ value and the supporting electrolyte composition. For both electrodes, no reduction signals corresponding to the anodic responses were observed on the cathodic branch by reversing at $1.8 \mathrm{~V}$. The MIR peak decreased to the second or higher cycles for both electrodes. This phenomenon may be partly attributed to the consumption of adsorbed MIR on the electrode surface. The repetitive cyclic voltammograms of MIR are shown at the GC and BDD electrodes in $\mathrm{pH} 7.0$ and 8.0 Britton-Robinson solutions, respectively, within $0-1.8 \mathrm{~V}$ at a scan rate $100 \mathrm{mV} / \mathrm{s}$ (Figure 1).
Comparison of the response at the $\mathrm{GC}$ electrode with that at the BDD electrode revealed potential shifts (to less negative potentials) of about $70 \mathrm{mV}$ in all kinds of supporting electrolyte. These shifts clearly show that the investigated compound was more easily oxidized on the GC electrode than the BDD electrode. Nevertheless, the peak was broad and small at the GC electrode and lower background currents were obtained using the BDD electrode compared with the GC electrode in Figure 1. Also, the peak potentials shifted to more positive potentials, about $145 \mathrm{mV}$ for the BDD electrode and about $96.0 \mathrm{mV}$ for the GC electrode in the anodic direction, when the scan rate was increased.

Next, the impact of $\mathrm{pH}$ on the anodic peak at the GC and BDD electrodes was investigated. The effect of $\mathrm{pH}$ on peak potential and peak intensity was studied in detail using the CV, DPV and SWV techniques for both electrodes between $\mathrm{pH} 0.3$ and 12.0. All graphs from all techniques were similar. For this reason, only the DPV results for the anodic response are given as $E_{\mathrm{p}}-\mathrm{pH}$ and $\mathrm{I}_{\mathrm{p}}-\mathrm{pH}$ graphs in Figures $2 \mathrm{a}$ and $2 \mathrm{~b}$ for the $\mathrm{GC}$ electrode and in Figures $2 \mathrm{c}$ and $2 \mathrm{~d}$ for the BDD electrode, respectively. The observed $\mathrm{pH}$ dependence indicates that the electroactive group (piperazine ring) corresponding to the MIR main oxidation peak was in acid-base equilibrium with a $\mathrm{pK}_{\mathrm{a}}$ of about 8.0 for both electrodes. The position of the break was close to the $\mathrm{pK}_{\mathrm{a}}$ value of MIR, at about 7.7 [30]. Above pH 8.0, the peak potential nearly became $\mathrm{pH}$ independent (Figures $2 \mathrm{a}, 2 \mathrm{c})$. This break could be due to a change in the protonation-deprotonation process of the piperazine molecule. The $\mathrm{pH}$ independent zone above $\mathrm{pH} 8.0$ means that there are no proton transfer steps before the electron transfer ratedetermining step; thus, the oxidation potential remains $\mathrm{pH}$ independent for both electrodes. At $\mathrm{pH}<\mathrm{pK}_{\mathrm{a}}$, the conjugate base must be formed by rapid dissociation of the protonated form.

In the linear part of Figures 2a and 2c, a disharmony was obtained between sulfuric acid $(0.1$ and $0.5 \mathrm{M})$, phosphate $(0.2 \mathrm{M})$, Britton- 


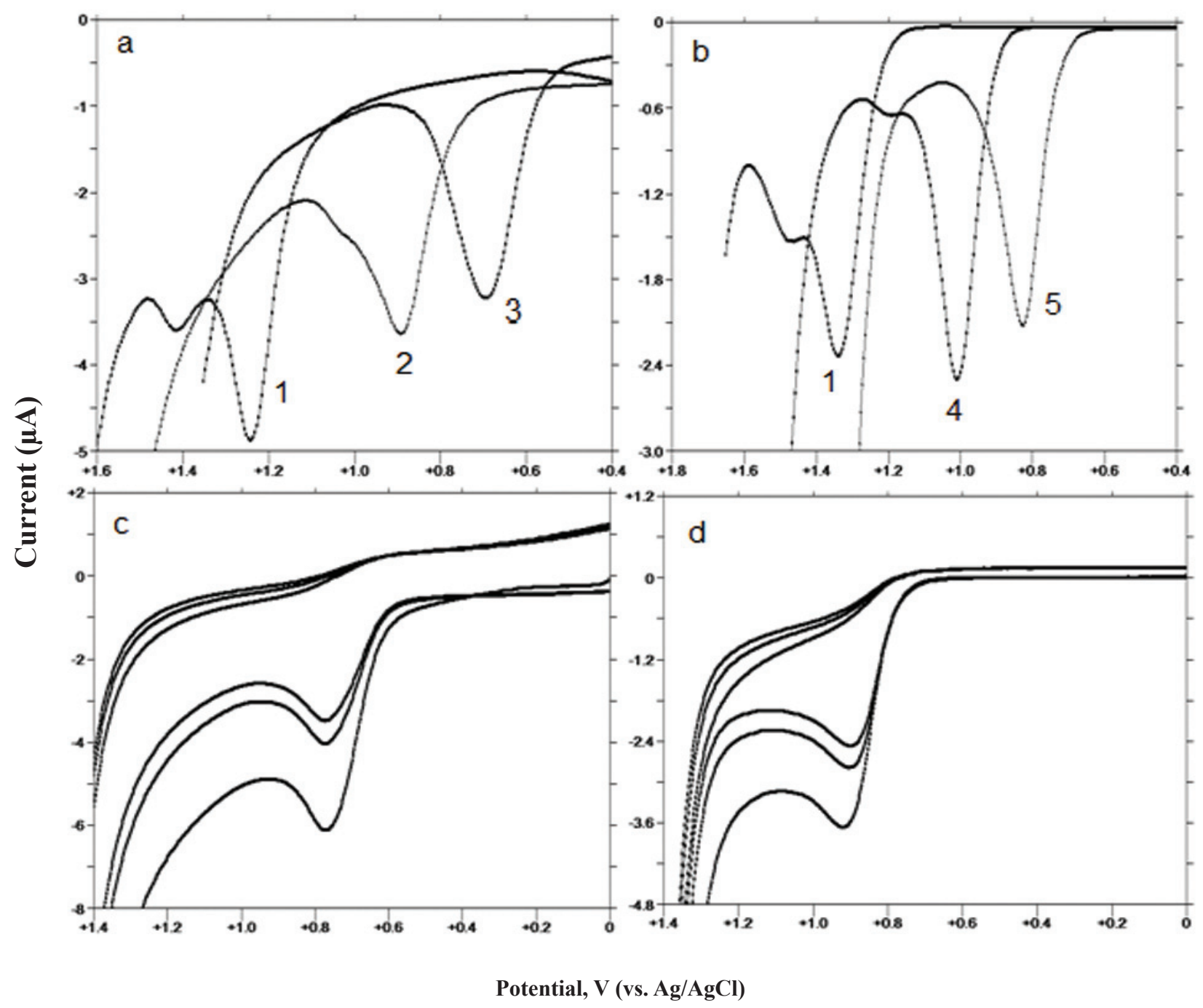

Fig. 1. DP ( $a$ and b) voltammograms of $1.062 \mu \mathrm{g} / \mathrm{ml} \mathrm{MIR}$ in $0.5 \mathrm{M} \mathrm{H}_{2} \mathrm{SO}_{4}(1)$; phosphate buffer at $\mathrm{pH} 4.00$ (2); Britton-Robinson buffer at $\mathrm{pH} 7.00$ (3); acetate buffer at $\mathrm{pH} 4.50$ (4); Britton-Robinson buffer at $\mathrm{pH} 8.00$ (5) for GC (a) and BDD (b) electrodes. Repetitive cyclic voltammograms of $1.062 \mu \mathrm{g} / \mathrm{ml}$ MIR in Britton-Robinson buffer at $\mathrm{pH} 7.00$ for the GC electrode (c) and $\mathrm{pH} 8.00$ for the BDD electrode (d). Scan rate, $100 \mathrm{mV} / \mathrm{s}$.

Robinson $(0.04 \mathrm{M})$ and acetate buffers $(0.2 \mathrm{M})$ in the $\mathrm{pH}$ range of $0.3-12.0$. This may be due to the differences in the ionic strength and the ionic species of the buffers.

Linear segments can be expressed by the following equations for the main peak using the DPV technique.

$$
E_{\mathrm{p}}=1206.9-56.99 \mathrm{pH} ; r=0.938 \text { between }
$$
$\mathrm{pH} 0.3-11.0$ (for GC electrode);

$E_{\mathrm{p}}=1307.9-57.00 \mathrm{pH} ; r=0.997$ between $\mathrm{pH}$ 0.3-8.0 (for BDD electrode).
The slopes of these equations were found to be $-56.99 \mathrm{mV} / \mathrm{pH}$ for the $\mathrm{GC}$ electrode and $-57.00 \mathrm{mV} / \mathrm{pH}$ for the BDD electrode, respectively. These slopes were close to the expected theoretical value of $59 \mathrm{mV} / \mathrm{pH}$, indicating that the number of protons and electrons involved in the oxidation of MIR is equal, which confirms the results obtained with the model compounds.

The experimental results showed that only one anodic peak and maximum peak current was obtained, and was better at $\mathrm{pH}$ 7.0 

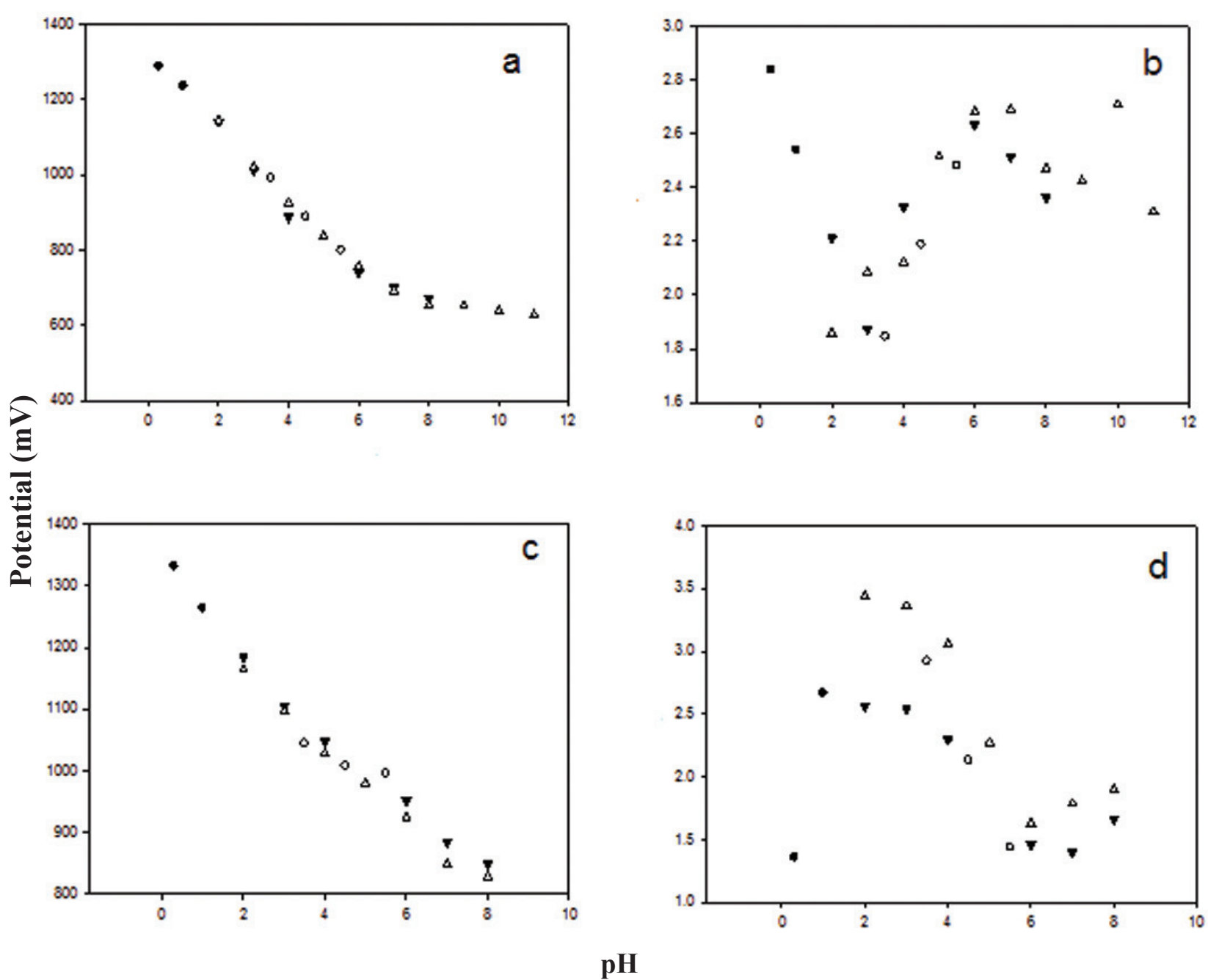

Fig. 2. Effect of $\mathrm{pH}$ on MIR peak potential (a, c) and peak current (b, d); MIR concentration $1.062 \mu \mathrm{g} / \mathrm{ml}$ with a constant amount of methanol $(10 \%)$ with $\mathrm{GC}(\mathrm{a}, \mathrm{b})$ and $\mathrm{BDD}(\mathrm{c}, \mathrm{d})$ electrodes

$(\bullet) \mathrm{H}_{2} \mathrm{SO}_{4}(0.5 \mathrm{M})$; $(\Delta)$ Britton-Robinson $(0.04 \mathrm{M})$;

$(\boldsymbol{\nabla})$ phosphate $(0.2 \mathrm{M})$ and $(\mathrm{o})$ acetate buffers $(0.2 \mathrm{M})$.

and 8.0 Britton-Robinson buffer with a constant amount of methanol (10\%) than with the other buffers and $\mathrm{pH}$ values for the $\mathrm{GC}$ electrode and the BDD electrode, respectively. For this reason, Britton-Robinson buffer solution at $\mathrm{pH} 7.0$ and 8.0 was chosen for the calibration equations.

The effects of scan rate on the oxidation of MIR were checked by LSV in $0.5 \mathrm{M}$ sulfuric acid, $\mathrm{pH} 4.0, \mathrm{pH} 6.0$ and $\mathrm{pH} 8.0$ phosphate buffer solutions for the $\mathrm{GC}$ electrode and 0.1 $\mathrm{M}$ sulfuric acid, $\mathrm{pH} 2.0, \mathrm{pH} 4.0$ and $\mathrm{pH} 8.0$
Britton-Robinson buffer solutions for the BDD electrode. The oxidation peak shifted towards more positive potentials as the scan rate increased, which is typical behavior of irreversible electrochemical reactions. The anodic peak current of MIR increased linearly with the root of the scan rate $\left(v^{1 / 2}(\mathrm{mV} / \mathrm{s})\right)$ and a plot of the logarithm of peak current (log $\left.I_{\mathrm{p}}\right)$ versus logarithm of scan rate $(\log v)$ gave a straight line in the range of $5-1000 \mathrm{mV} / \mathrm{s}$. These equations are given in Table 1. 
Table 1

Equations of scan rate study for $26.54 \mu \mathrm{g} / \mathrm{ml}$ MIR in the range of $5-1000 \mathrm{mV} / \mathrm{s}$

\begin{tabular}{lccccc}
\hline \hline & $n$ & $I_{\mathrm{p}}(\mu \mathrm{A})-v^{1 / 2}$ Equations $^{a}$ & $r$ & $\log I_{\mathrm{p}}-\log v$ Equations & $r$ \\
\hline $\mathrm{GCE}$ & & & & & \\
$0.5 \mathrm{M} \mathrm{H}_{2} \mathrm{SO}_{4}$ & 10 & $0.15 v^{1 / 2}+0.56$ & 0.987 & $0.39 \log v-0.45$ & 0.997 \\
$\mathrm{pH} \mathrm{4.0} \mathrm{phosphate} \mathrm{buffer}$ & 10 & $0.28 v^{1 / 2}-0.62$ & 0.979 & $0.53 \log v-0.74$ & 0.986 \\
$\mathrm{pH} 6.0$ phosphate buffer & 10 & $0.40 v^{1 / 2}-0.36$ & 0.996 & $0.52 \log v-0.47$ & 0.998 \\
$\mathrm{pH} 8.0 \mathrm{BR}$ buffer & 10 & $0.32 v^{1 / 2}+0.057$ & 0.999 & $0.51 \log v-0.51$ & 0.999 \\
\hline $\mathrm{BDDE}$ & & & & \\
$0.1 \mathrm{M} \mathrm{H}_{2} \mathrm{SO}_{4}$ & 10 & $0.23 v^{1 / 2}+0.38$ & 0.998 & $0.44 \log v-0.45$ & 0.998 \\
$\mathrm{pH} \mathrm{2.0} \mathrm{BR} \mathrm{buffer}$ & 10 & $0.40 v^{1 / 2}-0.17$ & 0.998 & $0.52 \log v-0.46$ & 0.999 \\
$\mathrm{pH} \mathrm{4.0} \mathrm{BR} \mathrm{buffer}$ & 10 & $0.33 v^{1 / 2}+0.17$ & 0.998 & $0.49 \log v-0.43$ & 0.999 \\
$\mathrm{pH} \mathrm{8.0} \mathrm{BR} \mathrm{buffer}$ & 10 & $0.21 v^{1 / 2}+0.37$ & 0.998 & $0.44 \log v-0.48$ & 0.999 \\
\hline \hline
\end{tabular}

${ }^{a}$ Obtained from five measurements

The slopes were close to the theoretical value of 0.5 , which is expected for an ideal reaction of solution species and different $\mathrm{pH}$ values. All correlation coefficients of $I_{\mathrm{p}}$ versus $v^{1 / 2}$ and the slopes of $\log I_{\mathrm{p}}$ versus $\log v$ also confirm the diffusion-controlled nature of the electrode process.

The potential $\left(E_{\mathrm{p}}\right)$ of the irreversible peak was shifted to more positive potentials with increasing sweep rate. According to the obtained slope values of plots of $E_{\mathrm{p}}$ versus $\log v$, the number of electrons was found to be 1.89 for the GC electrode 1.88 for the BDD electrode. These values were close to 2 , indicating that two electrons and two protons are involved in the ratedetermining steps.

The MIR molecule is extensively metabolized in vivo [24, 32]. Even though the exact oxidation mechanism has not been determined, some conclusions about the potentially electroactive centers under working conditions could be reached. To identify the responsible group for the oxidation of MIR, it was compared with some selected compounds which contain similar electroactive groups. CV curves from the redox properties of active drug compounds and biomolecules might have profound effects on the understanding of the redox mechanism related to the activity of MIR. It is assumed that oxidation occurred first on the nitrogen atom of the piperazine ring of the molecule. To support the working hypothesis that the piperazine ring in MIR undergoes oxidation, the behavior of the main anodic oxidation peak of MIR was compared with that of some model compounds. As model compounds for oxidation of the piperazine ring, we used quetiapine, piribedil, nefazodone and sildenafil citrate. These drugs, which all include a piperazine ring, were investigated by $\mathrm{CV}$ at the $\mathrm{GC}$ and/or BDD electrodes as a function of $\mathrm{pH}$ in order to identify the main oxidation behavior of MIR. Nefazodone and piribedil were oxidized over most of the $\mathrm{pH}$ range in a single peak. The peak potentials shifted with increasing $\mathrm{pH}$ to less positive potentials, similar to the potential of MIR. In sildenafil citrate and quetiapine, the monoprotonated form of the piperazine ring is rapidly generated from the di-cation, and is oxidized at about $\mathrm{pH} 7.0[31,32]$. The intersection of the $E_{\mathrm{p}} \mathrm{pH}$ curve of MIR and the other model compounds is located around 7.0, close to the $\mathrm{pK}_{\mathrm{a}}$ of the piperazine moiety [24]. This can be explained by the similarities of these compounds in terms of changes in the protonation of acid-base functions in the molecule. All model compounds included a piperazine ring, and we may assume that the first oxidation step of MIR is located on the piperazine moiety, which represents a typical 
redox system with two-electron oxidation processes in acidic and basic media. For all model substances, the intersection at about 7.0 or 7.5 was found to correspond to the $\mathrm{pK}_{\mathrm{a}}$ value of the piperazine moiety [24].

Thus, we might postulate that when the aliphatic nitrogen in the piperazine moiety (distal to the benzene ring of the molecule) is protonated, oxidation occurs on the proximal nitrogen with the removal of the proton. Above $\mathrm{pH}$ 8.0, oxidation occurs exclusively at the most basic piperazine nitrogen (distal) [24]. MIR loses an electron to form a cation radical, which upon losing a proton and an electron in subsequent steps forms a quaternary Schiff base.

The second step of MIR is comparable to pyridine oxidation, as reported in the literature $[24,34,35]$. To support the working hypothesis that the pyridine group (similar to pioglitazone and rosiglitazone) of MIR undergoes oxidation behavior, the small anodic wave related to the second response was compared to that of the model compounds. The electrochemical behavior of the second response of MIR at both electrodes showed that this ill-defined oxidation process is located on the pyridine ring of the molecule. We may suggest that the second anodic response could be attributed to the oxidation of the nitrogen atom on the pyridine ring [24, 34].

Our results on the model compounds confirm that the electroactive centers corresponding to the first and second responses are the nitrogen atoms on the piperazine and pyridine ring, respectively.

\subsection{Controlled potential coulometry}

Controlled potential coulometry was applied to obtain the number of transferred electrons; $n$ values were calculated from the charge consumed by a low concentration of MIR. The total charge consumed for electrolysis was measured and substituted into Faraday's equation: $Q=$ $n F N$, where $Q$ is the total charge consumed by electrolysis, $F$ is the Faraday's constant $(96,500$ C), and $N$ is the number of molar equivalents.
Using Faraday's equation, the number of transferred electrons was calculated. A $4 \times 10^{-9} \mathrm{M}$ MIR solution was purged with nitrogen. The solution was stirred continuously during electrolysis. The total charge consumed was $682 \mu \mathrm{C}$ and the number of electrons transferred was 2 , determined by controlled potential coulometry.

\subsection{Specificity and stress-degradation studies}

Specificity is described as the ability of the method to determine the analytes from all potential interfering substances [29]. The specificity of the developed RP-LC method for MIR was assayed in the presence of excipients in its pharmaceutical dosage forms and degradation products. Degradation peaks were separated from the main peaks.

Table 2 shows the results of the forced degradation studies using the proposed LC method, indicating the degradation percentage and purity of the MIR peak in chromatograms. The degradation products of each of the parent compounds were found to be similar under different drastic stress conditions. Typical chromatograms obtained following the assay of the untreated standard samples are given in Figure 3a and samples stressed under drastic conditions are shown in Figures $3 \mathrm{~b}-\mathrm{f}$.

Table 2

The results of hydrolytic, oxidizing, thermal and photolytic drastic stress conditions

\begin{tabular}{ll}
\hline \hline $\begin{array}{l}\text { Response to } \\
\text { stress conditions }\end{array}$ & $\begin{array}{l}\text { Degradation } \\
\text { of } \text { MRT }^{a}(\%)\end{array}$ \\
\hline $\mathrm{HCl}(0.5 \mathrm{M})$ & 54.85 \\
$\mathrm{HCl}(1 \mathrm{M})$ & 74.78 \\
$\mathrm{NaOH}(0.5 \mathrm{M})$ & 0.71 \\
$\mathrm{NaOH}(1 \mathrm{M})$ & 0.98 \\
$\mathrm{H}_{2} \mathrm{O}_{2}(3 \%)$ & 28.36 \\
$\mathrm{H}_{2} \mathrm{O}_{2}(30 \%)$ & 79.27 \\
$\mathrm{UV}(24 \mathrm{~h})$ & 8.92 \\
$\mathrm{Heating}\left(75^{\circ} \mathrm{C} 24 \mathrm{~h}\right)$ & 3.08 \\
Heating $\left(100^{\circ} \mathrm{C} 24 \mathrm{~h}\right)$ & melting \\
\hline \hline
\end{tabular}

${ }^{a}$ Each value is the mean of three experiments. 


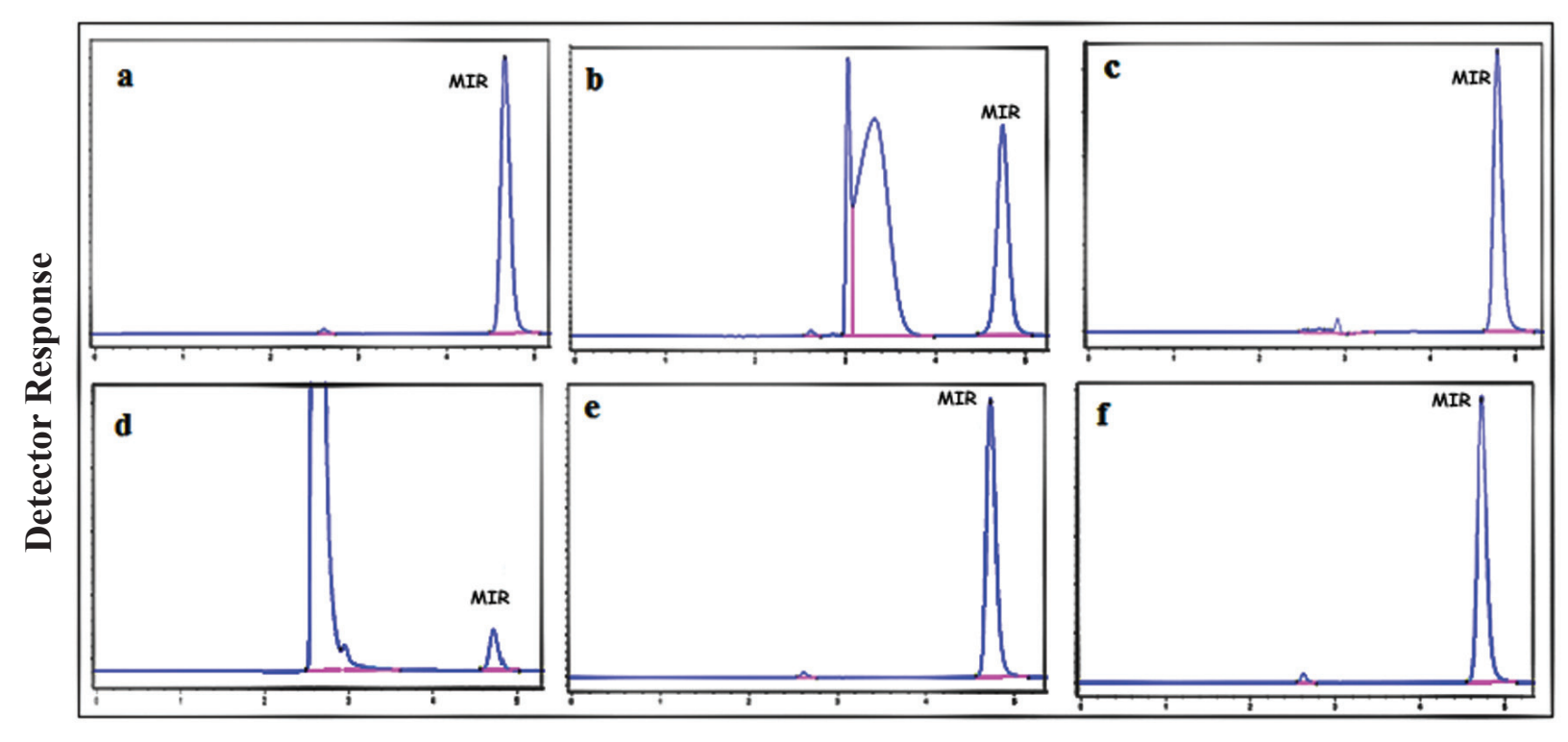

Time (min)

Fig. 3. Typical LC chromatograms of the pure bulk sample of $100 \mu \mathrm{g} / \mathrm{ml}$ MIR (a) and drastic stressed conditions of samples: (b) $1 \mathrm{~N} \mathrm{HCl}$ at $80{ }^{\circ} \mathrm{C}$ after $30 \mathrm{~min}$; (c) $1 \mathrm{~N} \mathrm{NaOH}$ at $80{ }^{\circ} \mathrm{C}$ after $30 \mathrm{~min}$; (d) $\mathrm{H}_{2} \mathrm{O}_{2} 30 \%$ at $80{ }^{\circ} \mathrm{C}$ after $30 \mathrm{~min}$; (e) in UV light (254 nm) after $24 \mathrm{~h}$; (f) at $100^{\circ} \mathrm{C}$ after $24 \mathrm{~h}^{2}$

Stress-degradation studies of drug substances can help to identify the possible degradation products. Hence, the degradation pathways, the intrinsic stability of the molecule and the stability-indicating power of the analytical procedures can be established. The specificity of the developed RP-LC method for MIR was assayed in the presence of its pharmaceutical formulations and degradation products. Voltammetric methods do not allow for the separation of degradation products from the main compound. Therefore, only the RP-LC method is reported for the specificity studies.

Degradation experiments were designed using acidic and alkaline hydrolysis, hydrogen peroxide, dry heat and UV light. Typical chromatograms obtained following the assay of the untreated standard samples and stressed samples using drastic conditions are shown in Figure 3. MIR was clearly degraded during heating, UV light exposure, acidic hydrolysis and alkaline hydrolysis. Oxidation (Table 2) led to the formation of some unknown degradation peaks (Figures $3 \mathrm{~b}-\mathrm{f}$ ). The MIR response was successfully resolved from the degradation products with the proposed RP-LC method, as shown in Figure 3. The percentages of degraded compound are reported in Table 2.

\subsection{Assay methods for MIR}

\subsubsection{Voltammetric assay method results}

In order to develop a voltammetric method for determining MIR, the DPV and SWV techniques were selected. For these voltammetric studies, the effects of the amount of methanol on the peak current and potential were studied. For analytical purposes, the best response was obtained by working with a $10 \%$ constant amount of methanol at $\mathrm{pH} 7.0$ and 8.0 in Britton-Robinson buffer for the GC and BDD electrodes, respectively. Under the chosen experimental conditions, the variation in the peak current with increasing concentrations of MIR was analyzed by means of DPV and SWV for both electrodes (Figure 4).

The good linearity of the calibration graph and the negligible scatter of the experimental 

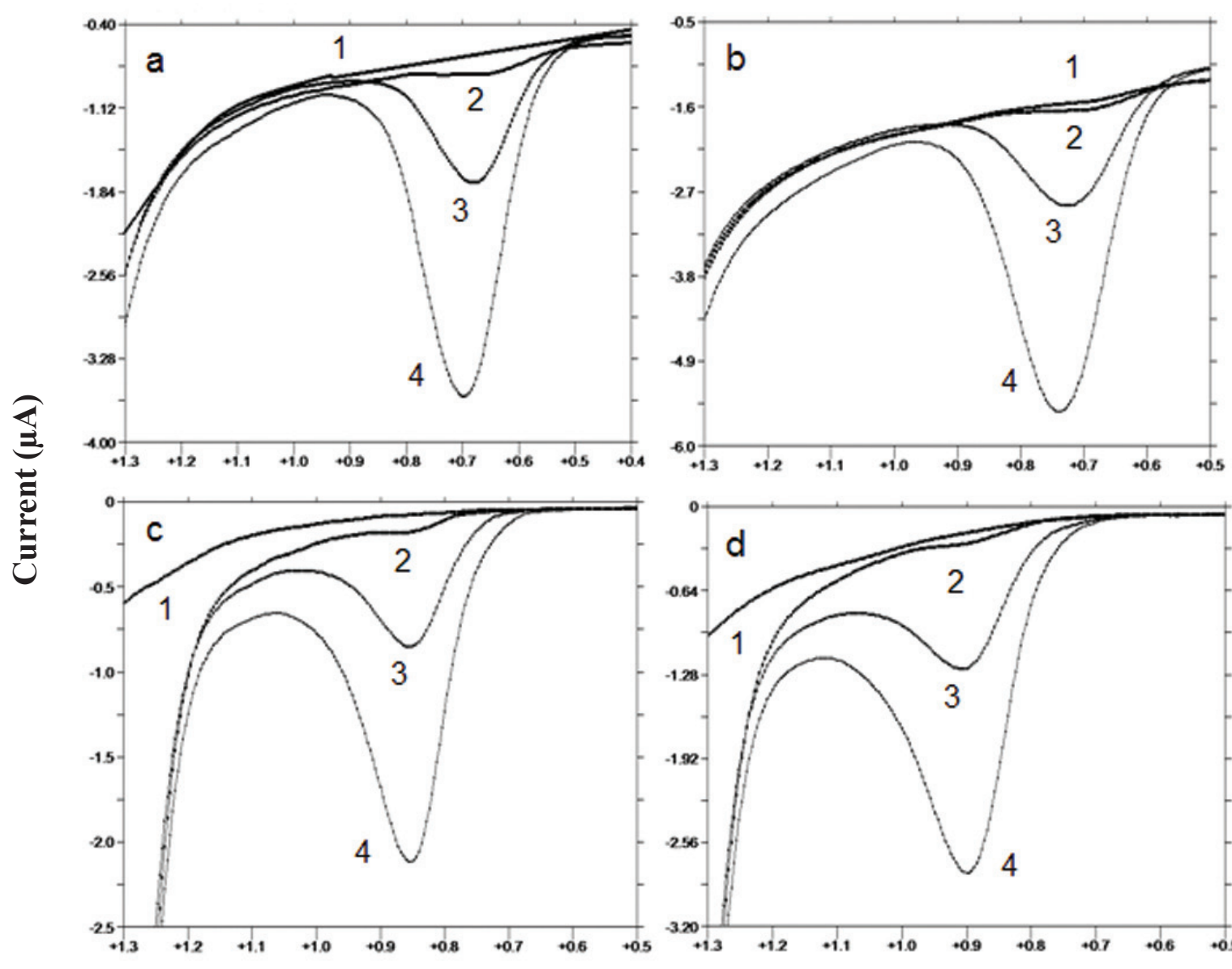

Potential, V (vs. Ag/AgCl)

Fig. 4. DPV (a and c) and SWV (b and d) obtained for the determination of MIR using GC (a and b) and BDD (c and d) electrodes. (1) Supporting electrolyte $\mathrm{pH}$ 7.0 Britton-Robinson buffer for GC and $\mathrm{pH} 8.0$ BrittonRobinson buffer for BDD; (2) $1.062 \mu \mathrm{g} / \mathrm{ml}$; (3) $10.62 \mu \mathrm{g} / \mathrm{ml}$ and (4) $26.54 \mu \mathrm{g} / \mathrm{ml} \mathrm{MIR} \mathrm{in}$ $0.5 \mathrm{M} \mathrm{H}_{2} \mathrm{SO}_{4}$ solution with a constant amount of methanol (10\%).

points are evident by the values of the correlation coefficient and standard deviation.

A calibration graph from the standard solution of MIR was carried out using DP and SW voltammetry. The peak current at the potential of $+1.0 \mathrm{~V}$ increased proportionally with the MIR concentration to yield a highly linear calibration plot.

$$
\begin{gathered}
I_{\mathrm{r}}(\mu \mathrm{A})=27456 \mathrm{C}(\mathrm{M})-0.0113 \\
(r=0.999 ; n=7 \mathrm{DPV}) ; \\
I_{\mathrm{r}}(\mu \mathrm{A})=37052 \mathrm{C}(\mathrm{M})-0.0301 \\
(r=0.999 ; n=7 \mathrm{SWV}) \text { for the GC electrode; } \\
I_{\mathrm{r}}(\mu \mathrm{A})=16508 \mathrm{C}(\mathrm{M})-0.0257 \\
(r=0.999 ; n=7 \mathrm{DPV}) ; \\
I_{\mathrm{r}}(\mu \mathrm{A})=22437 \mathrm{C}(\mathrm{M})-0.0918 \\
(r=0.998 ; n=7 \mathrm{SWV}) \text { for the BDD electrode. }
\end{gathered}
$$

The low values of standard error of the slope, intercept and greater correlation coefficient than 0.999 confirmed the precision of the voltammetric methods. The characteristics of the calibration equations and related validation parameters are summarized in Table 3.

LOD and LOQ values were calculated from the equations as $\mathrm{LOD}=3.3 \mathrm{~s} / \mathrm{m}$ and $\mathrm{LOQ}=10$ $\mathrm{s} / \mathrm{m}$, respectively, [27] using the standard deviation of response and the slope of the calibration curve.

The repeatability and reproducibility of peak potential and peak current were tested on $26.54 \mu \mathrm{g} / \mathrm{ml}$ MIR. The RSD\% values are shown in Table 3. The precision and sensitivity of the proposed methods can easily be established from the low SE value of the slope and intercept. 
Table 3

Regression data of the calibration lines for quantitative determination of MIR by DPV and SWV for the GC and BDD electrodes and the LC method

\begin{tabular}{|c|c|c|c|c|c|}
\hline & \multicolumn{2}{|c|}{$\mathrm{GC}$} & \multicolumn{2}{|c|}{ BDD } & \multirow{2}{*}{ LC-UV method } \\
\hline & DPV & SWV & DPV & SWV & \\
\hline Measured potential (V) & 0.692 & 0.732 & 0.828 & 0.864 & \\
\hline Retention time (min) & & & & & 4.65 \\
\hline Linearity range $(\mu \mathrm{g} / \mathrm{ml})$ & $0.212-26.54$ & $0.212-26.54$ & $0.212-26.54$ & $1.061-26.54$ & $1.00-18.00$ \\
\hline Slope $\left(\times 10^{3}\right)$ & 27.46 & 37.05 & 16.51 & 22.44 & 0.226 \\
\hline Intercept & -0.011 & -0.0301 & -0.0257 & -0.0918 & -0.079 \\
\hline Correlation coefficient & 0.999 & 0.999 & 0.999 & 0.998 & 0.999 \\
\hline SE of slope $\left(\times 10^{3}\right)$ & 0.261 & 0.267 & 0.148 & 0.524 & 2.210 \\
\hline SE of intercept $\left(\times 10^{-2}\right)$ & 1.122 & 1.148 & 0.636 & 2.604 & 2.192 \\
\hline $\mathrm{LOD}(\mu \mathrm{g} / \mathrm{ml})$ & 0.0031 & 0.0018 & 0.0060 & 0.0013 & 0.015 \\
\hline LOQ $(\mu \mathrm{g} / \mathrm{ml})$ & 0.0092 & 0.0055 & 0.0183 & 0.0038 & 0.051 \\
\hline $\begin{array}{l}\text { Repeatability of peak current / } \\
\text { peak area }(\mathrm{RSD} \%)^{a}\end{array}$ & 0.133 & 0.285 & 0.296 & 0.109 & 0.139 \\
\hline $\begin{array}{l}\text { Repeatability of peak potential / } \\
\text { retention time (RSD\%) }\end{array}$ & 0.337 & 0.581 & 0.255 & 0.245 & 0.060 \\
\hline $\begin{array}{l}\text { Reproducibility of peak current / } \\
\text { peak area }(\mathrm{RSD} \%)^{a}\end{array}$ & 0.502 & 0.743 & 0.617 & 0.288 & 0.278 \\
\hline $\begin{array}{l}\text { Reproducibility of peak potential / } \\
\text { retention time (RSD\%) })^{a}\end{array}$ & 0.751 & 0.778 & 1.22 & 1.07 & 0.067 \\
\hline
\end{tabular}

${ }^{a}$ Obtained from five experiments

\subsubsection{RP-LC assay results}

In RP-LC methods, precision and accuracy can often be enhanced by the use of an appropriate IS, which also compensates for changes in sample size or concentration due to instrumental variations. Also, the proposed method has the advantage of using an IS which compensates for any error that may occur due to baseline drift or fluctuations in the readings of the DAD detector. Ideally, an IS should display similar physicochemical properties to the analyte. Several compounds were tested; hydrochlorothiazide was chosen as the IS because it showed a shorter retention time with better peak shape and better resolution from the investigated compound peak compared with the other potential IS compounds. After determining the optimum conditions, satisfactory resolution was obtained in a short analysis time $(5 \mathrm{~min})$. The retention times of MIR and the IS were 4.65 and $3.27 \mathrm{~min}$, respectively (Figure 5).
The system suitability parameters have already been calculated for this method. Tailing factors and theoretical plate numbers were obtained as 1.17 and 9985 for MIR and 1.20 and 8544 for the IS, respectively, for this system. All results conformed to USP requirements for system suitability tests.

The linearity of the detector responses for MIR was determined by the plotting peak area ratio of the drug to the IS versus concentration. The analytical data for the calibration graph are listed in Table 3 . The calibration curve was linear in the range of $1.0-18.0 \mu \mathrm{g} / \mathrm{ml}$ at a detection wavelength $230 \mathrm{~nm}$, with a correlation coefficient $(r)$ of 0.999 .

The stability of the reference substances and sample solutions were checked by analyzing a prepared standard solution of MIR stored at $+4{ }^{\circ} \mathrm{C}$ in the dark against a freshly prepared sample using both the voltammetric and LC methods. The results demonstrated that the 


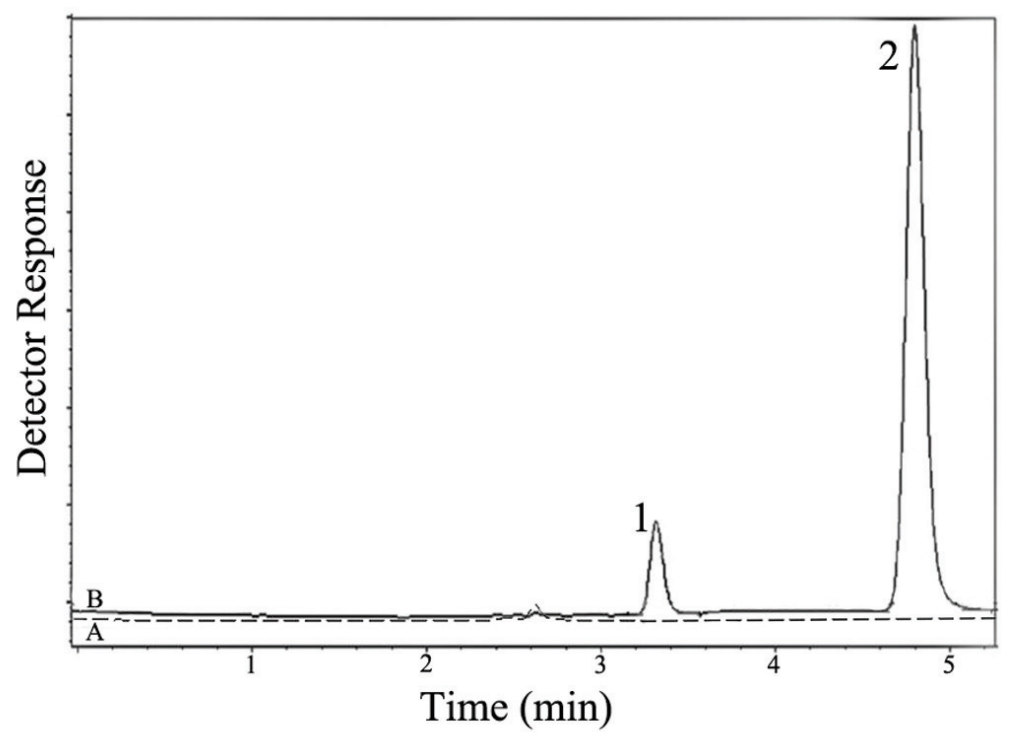

Fig. 5. Typical LC chromatograms of (A) (----) methanol:water $(30: 70, V / V)$ adjusted to $\mathrm{pH} 3.0$ as the mobile phase and (B) (—) pharmaceutical dosage form of $5.0 \mu \mathrm{g} / \mathrm{ml}$ IS (1) and $30.0 \mu \mathrm{g} / \mathrm{ml} \mathrm{MIR} \mathrm{(2).}$

Experimental conditions were as in the chromatographic procedure.

working standard solutions were stable for at least $72 \mathrm{~h}$.

The adequacy of the developed methods was evaluated by quantifying MIR in the tablet dosage form (labeled value $30 \mathrm{mg}$ ). Either the voltammetric or LC method could be used for the assay of MIR without prior separation of the excipients. The concentration of MIR determined in the tablets using both methods is reported in Table 4 . The mean results for the determination of both proposed methods were found to be very close to the declared value of $30 \mathrm{mg}$ (Table 4).

T a b 1 e 4

The results for the determination of MIR from the dosage form and recovery experiments achieved by the GC and BDD electrode and the LC method

\begin{tabular}{|c|c|c|c|c|c|}
\hline \multirow{2}{*}{ Parameters } & \multicolumn{2}{|c|}{$\mathrm{GC}$} & \multicolumn{2}{|c|}{ BDD } & \multirow{2}{*}{ LC-UV } \\
\hline & DPV & SWV & DPV & SWV & \\
\hline Label claim (mg) & 30.00 & 30.00 & 30.00 & 30.00 & 30.00 \\
\hline Amount found ${ }^{a}(\mathrm{mg})$ & 30.09 & 30.06 & 30.04 & 30.04 & 29.95 \\
\hline RSD $\%$ & 0.465 & 0.265 & 0.061 & 0.066 & 0.230 \\
\hline Bias $\%$ & -0.300 & -0.200 & 0.133 & 0.133 & 0.167 \\
\hline$t_{\text {value }}$ & 0.090 & 0.054 & 0.032 & 0.028 & $t_{\text {theoretical }}: 2.31$ \\
\hline$F_{\text {value }}$ & 0.198 & 0.782 & 0.025 & 0.029 & $F_{\text {theoretical }}: 3.79$ \\
\hline Added (mg) & 15.00 & 15.00 & 15.00 & 15.00 & 4.000 \\
\hline Found $^{a}(\mathrm{mg})$ & 14.89 & 14.95 & 14.99 & 14.98 & 4.007 \\
\hline Average recovered (\%) & 99.95 & 100.04 & 100.06 & 100.09 & 100.07 \\
\hline $\mathrm{RSD} \%$ of recovery & 0.157 & 0.323 & 0.026 & 0.135 & 0.030 \\
\hline Bias $\%$ & 0.733 & 0.333 & 0.0667 & 0.133 & -0.175 \\
\hline
\end{tabular}

${ }^{a}$ Obtained from five experiments 


\subsubsection{Statistical comparison of the voltammetric and chromatographic methods}

In order to know whether the excipients, such as corn starch, hydroxypropyl cellulose, magnesium stearate, colloidal silica dioxide, lactose monohydrate, hydroxypropylmethyl cellulose, polyethylene glycol 8000, titanium dioxide, yellow and red iron oxides $(30 \mathrm{mg}$ ) [25], in the tablets and solutions showed any interference with the analysis, we also carried out recovery studies after the addition of known amounts of the pure drug to various preanalyzed formulations of MIR for both methods. Excipients present in the tablet did not interfere with the analysis (Table 4). These results show that the proposed methods had adequate precision and accuracy. As far as we know, no official or literature method has been described related to MIR analysis in the tablet dosage form. For this reason, we developed an RP-LC method as a comparison technique. These two methods were compared with each other using Student's $t$-tests and $F$-tests. At the $95 \%$ confidence level, the values of the $t$-tests and $F$-tests were less than that of the theoretical $t$ and $F$ values, showing that there were no significant differences in the performance of the proposed methods (Table 4).

\section{CONCLUSION}

The anodic voltammetric behavior and the determination of MIR in the dosage form were investigated for the first time in this study. The electrooxidation processes of MIR on carbonbased electrodes are irreversible and diffusion controlled procedures at all $\mathrm{pH}$ values and in all studied supporting electrolytes.

Either voltammetric or RP-LC methods provide a sensitive, simple, rapid and cost-effective determination of MIR in pharmaceuticals without the necessity of sample pretreatment, or any time consuming evaporation or extraction steps prior to analysis.

The results of stress testing undertaken according to the $\mathrm{ICH}$ guidelines reveal that the method is selective, specific and stabilityindicating. The proposed RP-LC method has the ability to separate MIR from its degradation products and related substances.

All of the proposed methods are suitable for quality control laboratories, where economy and time are essential. High percentage recoveries showed that the proposed methods are free from interference by commonly used excipients and additives in pharmaceutical dosage forms.

\section{REFERENCES}

[1] The Merck Index, $13^{\text {th }}$ ed., Whitehouse Station, NJ, 2001.

[2] P. M. Hartmann, Mirtazapine: a newer antidepressant, Am. Fam. Phys., 59, 159-161 (1999).

[3] D. Nutt, Mirtazapine: pharmacology in relation to adverse effects, Acta Psych. Scand., 96, 31-37 (1997).

[4] S. C. Sweetman, Martindale, The Extra Pharmacopoeia, 36th ed., Pharmaceutical Press, L o n d o n, 2009.

[5] X. Hong, Y. Yao, S. Hong, C. Lei, LC-MS-MS analysis of mirtazapine in plasma and determination of pharmacokinetic data for rats, Chromatogr., 68, 65-70 (2008).

[6] R. Mandrioli, L. Mercolini, N. Ghedini, C. Bartoletti, S. Fanali, M. A. Raggi, Determination of the antidepressant mirtazapine and its two main metabolites in human plasma by liquid chromatography with fluorescence detection, Anal. Chim. Acta., 556, 281-288 (2006).

[7] C. Pistos, M. Koutsopoulou, I. A. Panderi, A validated liquid chromatographic tandem mass spectrometric method for the determination of mirtazapine and demethylmirtazapine in human plasma: Application to a pharmacokinetic study, Anal. Chim. Acta., 514, 15-26 (2004).

[8] P. Ptacek, J. Klima, J. Macek, Determination of mirtazapine in human plasma by liquid chromatography, J. Chromatogr. B: Anal. Tech. Biomed. Life Sci., 794, 323-328 (2003).

[9] T. Romiguieres, F. Pehourcq, M. Matoga, B. Begaud, C. Jarry, Determination of mirtazapine and its demethyl metabolite in plasma by high-performance liquid chromatography with ultraviolet detection: Application to management of acute intoxication, Journal of Chromatogr. B: Anal. Tech. Biomed. Life Sci., 775, 163-168 (2002). 
[10] L. Labat, P. Dallet, E. Kumer, J. P. Dubost, Spectrophotometric, spectrofluorimetric, HPLC and CZE determination of mirtazapine in pharmaceutical tablets, J. Pharm. and Biomed. Anal., 28, 365-371 (2002).

[11] B. Saini, M. Kaushal, G. Bansal, A validated direct spectrofluorimetric method for quantification of mirtazapine in human whole blood, Spectroscopy., 24, 641-649 (2010).

[12] R. M. Youssef, Determination of mirtazapine in spiked human plasma and tablets by first derivative spectrofluorimetric method, Saudi Pharm. J., 18, 45-49 (2010).

[13] D. R. Kumar, V. N. Lakshmi, S. V. M Vardhan, C. Rambabu, Bioscien. Biotech. Res. Asia., 5, 863-866 (2008).

[14] N. Karaşen, S. Altinöz, Determination of mirtazapine in tablets by UV spectrophotometric and derivative spectrophotometric methods, J. Pharm. and Biomed. Anal., 24, 11-17 (2000).

[15] B. Uslu, S. A. Ozkan, Electroanalytical application of carbon based electrodes to the pharmaceuticals, Anal. Lett., 40, 817-853 (2007).

[16] B. Uslu, S. A. Ozkan, Solid electrodes in electroanalytical chemistry: Present applications and prospects for high-throughput screening of drug compounds, Comb. Chem. High Through. Screen., 10, 495-513 (2007).

[17] B. Uslu, S. A. Ozkan, H. Y. Aboul-Enein, Analysis of pharmaceuticals and biological fluids using modern electroanalytical techniques, Crit. Rev. Anal. Chem., 33, 155-181 (2003).

[18] M. R. Symth, J. G. Vos, Analytical Voltammetry, Vol. XXVIII of series, Comprehensive Analytical Chemistry, Amsterdam, 1992.

[19] R. N. Goyal, S. Chatterjee, A. R. S. Rona, A singlewall carbon nanotubes modified edge plane pyrolytic graphite sensor for determination of methylprednisolone in biological fluids, Talanta, 80, 586-592 (2009).

[20] J. Wang, Electroanalytical Techniques in Clinical Chemistry and Laboratory Medicine $\mathrm{VCH}$, New York, 1988.

[21] C. Wang, J. Guan, Q. Qu, G. Yang, X. Hu, Voltammetric determination of sinomenine in biological fluid using a glassy carbon electrode modified by a composite film of polycysteic acid and carbon nanotubes, Com. Chem. High Through. Screen., 10, 595603 (2007).

[22] B. Uslu, S. A. Ozkan, H. Y. Aboul-Enein, Electrochemical study of S-adenosyl-L-methionine and its differential pulse and square wave voltammetric determination, Electroanalysis, 14, 736-740 (2002).

[23] M. Gumustas, S. A. Ozkan, Electrochemical evaluation and determination of antiretroviral drug fosamprenavir using boron-doped diamond and glassy carbon electrodes, Anal. Bioanal. Chem., 397, 189-203 (2010).

[24] D. Kul, M. Gumustas, B. Uslu, S. A. Ozkan, Electroanalytical characteristics of antipsychotic drug ziprasidone and its determination in pharmaceuticals and serumsamples on solid electrodes, Talanta, 82, 286-295 (2010).

[25] http://www.merckfrosst.ca/assets/en/pdf/products/ Remeron-PM. Product monograph template-standard.

[26] S. A. Ozkan, Electroanalytical Methods in Pharmaceutical Analysis and Their Vaildation, $1^{\text {st }}$ ed., HNB Pub., 2011.

[27] C. M. Riley, T. W. Rosanske, Development and Validation of Analytical Methods, Elsevier, Amsterdam, the Netherlands, 1996.

[28] ICH, Stability testing of new drug substances and products (Q1AR): International Conference on Harmonization IFPMA, Geneva, 2000.

[29] ICH Harmonised Tripartite Guideline (2005) Validation of Analytical Procedures: Text and Methodology Q2(R1).

[30] N. L. Monser, M. Toumi, K. Boujlel, Determination of naproxen in pharmaceuticals by differential pulse voltammetry at a platinum electrode, Anal. Chim. Acta., 495, 69-75 (2003).

[31] B. Uslu, S. A. Ozkan, A rapid HPLC assay for the determination of lamivudine from pharmaceuticals and human serum, Anal. Chim. Acta., 462, 49 (2002).

[32] S. A. Ozkan, B. Uslu, P. Zuman, Electrochemical oxidation of sildenafil citrate (Viagra) on carbon electrodes. Anal. Chim. Acta., 501, 227 (2004).

[33] H. Lund, O. Hammerich, Organic Electrochemistry, Revised and Expanded, 4th ed., Marcel Dekker Inc. Pub., 2001.

[34] J. Grimshaw, Electrochemical Reactions and Mechanism in Organic Chemistry, 1st ed., Elsevier Science Publication, 2000.

[35] S. Suzen, B. T. Demircigil, E. Buyukbingol, S. A. Ozkan, Electroanalytical evaluation and determination of 5-(3'-indolal)-2-thiohydantoin derivatives by voltammetric studies: Possible relevance to in vitro metabolism, New J. Chem., 27, 1007 (2003). 
